\title{
Biochemical characterizations reveal different properties between CDK4/cyclin D1 and CDK2/cyclin A
}

\author{
Dong-Myung Kim ${ }^{1}$, Kyungmi Yang ${ }^{2}$ \\ and Beom-Seok Yang ${ }^{2,3}$ \\ ${ }^{1}$ Life Sciences R\&D, LGCI, 104-1 Moonji-dong \\ Yousung-gu, Daejon 305-380, Korea \\ ${ }^{2}$ Biomedical Research Center \\ Korea Institute of Science \\ and Technology, 39-1 Hawolgok-dong \\ Sungbuk-gu, Seoul, Korea, 136-791 \\ ${ }^{3}$ Corresponding Author: Tel, 82-2-958-5174; \\ Fax, 82-2-958-5909; E-mail, bsyang@kist.re.kr
}

Accepted 2 October 2003

Abbreviations: ATP, adenosine triphosphate; CDK, cell cycle dependent kinase; FBS: fetal bovine serum; GST: glutathione-Stransferase; MOI: multitude of infection; $\mathrm{RB}$, retinoblastoma protein; RBC: human RB C-terminal protein from amino acid 780 to 928; SDS: sodium dodesyl sulfate

\begin{abstract}
CDK2 and CDK4 known promoter of cell cycling catalyze phosphorylation of RB protein. Enzyme specificity between two CDKs that work at a different cell cycle phase is not clearly understood. In order to define kinase properties of CDK2 and CDK4 in complex with cycline $A$ or cycline $D 1$ in relation to their respective role in cell cycling regulation, we examined enzymatic properties of both CDK4/cycline D1 and CDK2/cycline $A$ in vitro. Association constant, $\mathrm{Km}$ for ATP in CDK4/cyclin D1 was found as $418 \mu \mathrm{M}$, a value unusually high whereas CDK2/cyclin A was $23 \mu \mathrm{M}$, a value close to most of other regulatory protein kinases. Turnover value for both CDK4/cyclin D1 and CDK2/cyclin A were estimated as 3.4 and 3.9 $\mathrm{min}^{-1}$ respectively. Kinetic efficiency estimation indicates far over one order magnitude less efficiency for CDK4/cyclin D1 than the value of CDK2I cycline $A\left(9.3 \mathrm{pM}^{-1} \mathrm{~min}^{-1}\right.$ and $170 \mathrm{pM}^{-1} \mathrm{~min}^{-1}$ respectively). In addition, inhibition of cellular CDK4 caused increase of cellular levels of ATP, even though inhibition of CDK2 did not change it noticeably. These data suggest cellular CDK4/ cyclin D1 activity is tightly associated with cellular ATP concentration. Also, analysis of phosphorylated serine/threonine sites on RB catalyzed by CDK4/
\end{abstract}

cyclin D1 and CDK2/cyclin A showed significant differences in their preference of phosphorylation sites in RB C-terminal domain. Since RB is known to regulate various cellular proteins by binding and this binding is controlled by its phosphorylation, these data shown here clearly indicate significant difference in their biochemical properties between CDK4/cyclin D1 and CDK2/cyclin A affecting regulation of cellular $R B$ function.

Keywords: CDK2/cyclin A; CDK4/cyclin D1; cell cycle; $\mathrm{Km}$ for ATP; p16; RB phosphorylation site

\section{Introduction}

Cell cycle dependent protein kinase (CDK) family proteins possess a serine/threonine protein kinase activity and phosphorylate serine or threonine residue in front of proline with a consensus sequence of (S/T) $P(X)(K / R)$ (Endicott et al., 1999). Their major cellular role is suggested to be involved in the positive control of cell cycle progress. Various cell cycle dependent kinase family proteins; CDK1, CDK2, and CDK4 have been identified (Meyerson et al., 1992; Morgan, 1995). Each cell cycle dependent kinase needs to form a heteroduplex with a specific cyclin protein to become an active kinase (Sherr, 1994). Major cyclin proteins include cyclin B1, cyclin A, cyclin $E$ and D type cyclins. Each cyclin protein appears at a specific cell cycle phase, thus activates its partnering CDK (Sherr, 1994; Pavletich, 1999). CDK4 forms a complex with type D cyclins such as D1 and D2 and the cellular amount of cyclin D1 reaches to the highest level when cells are in Mid-G1, thus CDK4/cyclin D1 activity exists in mid $\mathrm{G} 1$ phase. Active CDK4/cyclin D1 is necessary to move cells from G0/G1 phase to $S$ phase (Baldin et al., 1993; Sherr, 1994). Therefore, the inhibition of CDK4/cyclin D1 activity renders cells arrested in G0/G1 phase (Bible et al., 1996; Sherr et al., 1999). When cells escape from proliferative phase to enter terminally differentiated stage, cyclin D1 protein disappears (Kiyokawa et al., 1994; Rao et al., 1994). Various mitogenic signaling elevates cyclin D1 expression, because cellular cyclin D1 level is sensitive to the mitogenic signaling such as ras signaling (Aktas et al., 1997). Cellular inhibition of CDK4/ cyclin D1 activity is also achieved by its inhibitory proteins, i.e. p16, p21 and p27 (Sherr, 1999). Among these, p16 is specific to CDK4, whereas p21 and p27 
are known to inhibit most CDKs such as CDK1, CDK2 and CDK4 (Endicott et al., 1999; Sherr et al., 1999). In almost $40 \%$ of human cancers, p16 gene mutation is observed. For this reason, it is classified as one of the important tumor suppressors (Liggett et al., 1998).

CDK2 is a homologous protein to CDK4 with about $47 \%$ homology in amino acid sequence. CDK2 forms a complex with cyclin $E$ or cyclin $A$ to be an active kinase complex (Morgan, 1995). Cyclin $E$ protein is transiently appeared when cells are in $\mathrm{G} 1$ to $\mathrm{S}$ phase transition (Koff et al., 1992). Cyclin A level is highest when cells are in $S$ phase, meaning that CDK2 kinase activity is a major active cell cycle dependent kinase in S phase (Guadagno et al., 1993). CDK2 was found to be included in a protein complex in vivo with cyclin A-Rb-E2F (Nevins et al., 1991; Brechot, 1993). In addition, CDK2/cyclin A effectively phosphorylates $\mathrm{Rb}$ protein in vitro and this phosphorylation prevents $\mathrm{E} 2 \mathrm{~F}$ binding to $\mathrm{Rb}$ (Suzuki-Takahashi et al., 1995). This suggests one of in vivo roles of CDK2/cyclin A activity is to free the transcription $E 2 F$ from $R b$ by phosphorylating $\mathrm{Rb}$ protein.

$\mathrm{RB}$ protein, a tumor suppressor protein is a major in vivo target for CDK kinase activity (Goodrich et al., 1991; Lin et al., 1991; Weinberg, 1995). RB protein possesses 10 serine/threonine residues with possible CDK phosphorylation consensus sequence and most these sequences exist in its C-terminal (Weinberg, 1995). Phosphorylation of RB C-terminal prevents transcription factor $E 2 F$ from binding to $R B$ protein, thus activating transcription activity of E2F (Stevens et al., 2003). E2F increases the transcription of genes promoting DNA replication and cell growth. Besides $\mathrm{E} 2 \mathrm{~F}$, so far more than 10 different proteins are shown to bind to RB protein and their binding is interfered when RB is phosphorylated by CDKs (Wang et al., 1993; Welch et al., 1993). All CDKs are known to phosphorylate RB protein in vitro (Weinberg, 1995). Cell cycle is very tightly controlled and its deregulation leads to cancer (Sherr, 1996). In many cancers, overexpressions of cyclin proteins and loss of CDK inhibitory proteins were observed (Sicinski et al., 1995; Serrano et al., 1996; Shin et al., 2000; Nam et al., 2001). In this reason, chemical inhibitors for CDKs have been developed and are being tested for the treatment of various human cancers (Fry et al., 2001; Soni et al., 2001; Tan et al., 2002).

Many studies on cell cycle dependent kinases have been done largely for their roles associated with cell cycle regulations at cellular level. However their detailed biochemical studies have not been sufficiently exploited yet. As a step to understand detailed biochemical events related to specific cell cycle phases, we need more knowledge of biochemical differences between CDKs. In this report, we carried out com- parative study on the enzymatic properties of the purified CDK4/cyclin D1 and CDK2/cyclin A.

\section{Materials and Methods}

\section{Construction of expression vectors and generation of baculovirus}

Human cDNAs for CDK4, CDK2, cyclin D1 and cyclin A were obtained by RT-PCR using mRNA purified from human fibroblast cells. Each cDNA was constructed as a baculoviral expression vector using pBacPak 8 vector (Clontech) by subcloning full length each cDNA into multicloning site on the vector. For the convenient affinity purification of expressed proteins, glutathione-S-transferase gene was fused to $\mathrm{N}$ terminal of CDK4 gene and CDK2 gene was tagged with hexahistidine at its $\mathrm{N}$-terminal. Each Baculovirus was generated using baculovirus generation Kit from ClonTech by cotransfecting the corresponding expression vector along with bacuroviral genomic DNA into sf9 cells. Each viral titer was infected into sf9 cells and the expression of the corresponding protein was confirmed by western blotting using specific antibodies. Human p16 cDNA was obtained by RT-PCR and its bacterial expression vector was generated by subcloning its full length cDNA on pET15b bacterial expression vector with hexa histidine tagging on its $\mathrm{N}$ terminal. Human RB C-terminal (a.a. 780 to 928) expression vector was also generated by subcloning on pET15b vector with hexa histidine tagging on its $\mathrm{N}$ terminal.

\section{Expressions and purifications of recombinant proteins}

GST-CDK4/cyclin D1 protein complex was obtained as follows. Sf9 cells were maintained in TNM-FH medium containing $10 \%$ FBS in culture dish. Baculovirus carrying GST-CDK4 gene and baculovirus of cyclin D1 were coinfected into sf9 cells with $10 \mathrm{MOI}$ and left for 2 days before harvest for protein purification. Infected $10^{9}$ cells were disrupted in $20 \mathrm{ml}$ of $20 \mathrm{mM}$ Tris ( $\mathrm{pH} 8.0$ ), $0.1 \mathrm{M} \mathrm{NaCl}, 5 \mathrm{mM}$ DTT, 0.5 $\mathrm{mM}$ EDTA, protease inhibitor cocktail (Roche), $10 \mathrm{mM}$ $\mathrm{NaF}$ by sonication. After centrifugation at $12,000 \mathrm{rpm}$ for 30 min using Sovall 34 rotor, the supernatant was loaded in Glutathione conjugated sepharose bead column (Amersham). Unbound proteins were washed

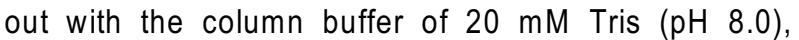
$0.1 \mathrm{M} \mathrm{NaCl}, 5 \mathrm{mM}$ DTT, $0.5 \mathrm{mM}$ EDTA and then bound protein was eluted using the column buffer containing $0.2 \mathrm{M}$ of reduced glutathione (Sigma). This eluate was diluted five fold to reduce $\mathrm{NaCl}$ concentration to $20 \mathrm{mM}$ and applied to $1 \mathrm{mM}$ bead volume of mono $Q$ column (Pharmacia-LKB). Bound proteins 
were eluted by increasing concentrations of $\mathrm{NaCl}$. For CDK2/cyclin A proteins, viruses carrying hexa histidine tagged CDK2 and cyclin A gene were coinfected into sf9 cells with $10 \mathrm{MOI}$. Cells were harvested after two days and $10^{9}$ cells were disrupted in $20 \mathrm{ml}$ of $20 \mathrm{mM}$ Tris ( $\mathrm{pH} 8.0$ ), $0.5 \mathrm{M} \mathrm{NaCl}, 1 \mathrm{mM}$ DTT, $0.5 \mathrm{mM}$ EDTA, protease inhibitor cocktail, 10 $\mathrm{mM} \mathrm{NaF}$ by sonication. CDK2/cyclin A complex where CDK2 has hexa histidine tagging in its $\mathrm{N}$-terminal, was purified using $\mathrm{Ni}^{2+}$ affinity column according to the protocol provided by the manufacturer (Novagen). The expression of human RB C-terminal protein from amino acid 780 to 928 (referred as $\mathrm{RBC}$ ) and $\mathrm{p} 16$ protein were performed in BL21 $E$. coli cells transformed by the expression vectors. Each gene has hexahistidine tagging on its $\mathrm{N}$ terminal. Proteins were purified using $\mathrm{Ni}^{2+}$-affinity column chromatography (Novagen) according to the manufacturer's manual.

\section{Standard enzyme assay}

Twenty $\mu$ of standard enzyme assay mixture for CDK4/cyclin D1 as well as CDK2/cyclin A contains $100 \mathrm{ng}$ of CDK enzyme, $10 \mu \mathrm{g}$ of purified RB Cterminal protein of a.a. 780-928 (RBC), $10 \mu \mathrm{M}$ ATP, $0.2 \mu \mathrm{Ci} \mathrm{p}{ }^{32}-\gamma$-ATP and $5 \mathrm{mM} \mathrm{MgCl}_{2}$ in $20 \mathrm{mM}$ Tris- $\mathrm{HCl}$ $(\mathrm{pH} 8.0)$. Enzyme reaction was carried for $10 \mathrm{~min}$ and stopped by adding half volume of $30 \%$ phosphoric acid. During $10 \mathrm{~min}$ reaction time, the reaction rate remains constant. The stopped mixture was spotted in P81 phosphocellulose paper (Whatman) and washed five times with $20 \mathrm{mM}$ Phosphate buffer ( $\mathrm{pH} \mathrm{6.0)}$ containing $100 \mathrm{mM} \mathrm{NaCl}$. The bound $\mathrm{p}^{32}$-radioactivity in each spot was quantitated using BAS counter (KODAK).

\section{Measurement of $\mathrm{Km}$ for ATP and turnover rate}

$\mathrm{Km}$ for ATP was measured using standard assay method except with the serial variation of ATP concentration. In the variation of ATP concentration, the ratio between cold and $p^{32}-\gamma$-ATP remains constant. The radioactivity on $\mathrm{RB} C$-terminal protein $(\mathrm{RBC})$ from $B A S$ counting was used as the relative enzyme activity and reciprocal plotting method was used to determine $\mathrm{Km}$ value. To determine turn over rate, ATP concentration of $1 \mathrm{mM}$ was used to confer the saturated concentrations of ATP in the enzyme reaction mixture. For other factors, the standard enzyme assay condition described above was used. After $10 \mathrm{~min}$ reaction, the same volume of $2 \times$ lameli buffer was added to the reaction mixture with subsequent boiling. The samples were separated on 15\% SDS-PAGE gel electrophoresis and stained with Coomagie brilliant blue. The RBC protein band with $\mathrm{p}^{32}$ radioactivity was excised and the radioactivity on the band was measured using scintillation counter. This measured radioactivity on $\mathrm{RB}$ protein band was compared to the total radioactivity added in initial enzyme reaction mixture. From the ratio of radioactivity on RB protein band to the total $p^{32}$ radioactivity in the initial reaction mixture, we could calculate the total mole number of phosphate transferred to RB protein during reaction. This is based on the fact that the ratio of radioactivity on $\mathrm{RB}$ protein band versus the total $\mathrm{p}^{32}$ radioactivity in the initial reaction mixture is exactly the same with the ratio of transferred phosphate moles on RB versus the initial ATP moles. The turn over rate was described as pico moles of phosphate transferred to RB C-terminal per min per pico mole of enzyme.

\section{Measurement of cellular ATP concentration}

HepG2 cells were grown and maintained using RPMI containing $10 \%$ fetal bovine serum. Using 6 well culture dish, $2 \times 10^{5}$ cells were plated on each well and grown overnight. Next day, $2 \mu \mathrm{M}$ of Flavopiridol $\left(\mathrm{IC}_{50}\right.$ for $\mathrm{CDK} 4 /$ cyclin D1: $70 \mathrm{nM}$ ) (kindly provided by Dr. SH Kim) and $20 \mu \mathrm{M}$ of Roscovitine (IC $\mathrm{C}_{50}$ for CDK2/cyclin A: $500 \mathrm{nM}$ ) (purchased from SIGMA) were treated on the HepG2 cells respectively. For measuring intracellular amount of ATP, we used ATP measuring kit (from SIGMA) that is based on the luciferase activation by depending on the amount of cellular ATP. Cells were lysed using the lysis buffer provided in the kit and $10 \mu \mathrm{l}$ was used to measure the luciferase activity using luminometer. The luciferase activity of each sample represents the relative amount of cellular ATP.

\section{Phospho-aminoacid analysis}

Four $\mu \mathrm{g}$ of RBC (human RB C-terminal) protein was subject to phosphorylation by CDK2/cyclin A or CDK4/ cyclin D1 in a standard reaction condition including $5 \mu \mathrm{ci}$ of $\mathrm{p}^{32}$-ATP and separated in $12 \%$ polyacrylamide gel electrophoresis and transferred to PVDF (polyvinylidone difluoride) membranes. The portion of membrane containing RBC protein was excised and hydrolyzed in $0.2 \mathrm{ml}$ of $6 \mathrm{~N} \mathrm{HCl}$ at $110^{\circ} \mathrm{C}$ for 1.5 h. Samples were then centrifuged at $12,000 \mathrm{~g}$ for 10 $\mathrm{min}$, and the supernatants were dried using speed Vac. The dried pellets were solubilized in a mixture of cold phosphoaminoacid standards (Ser(P), Thr(P), and $\operatorname{Tyr}(\mathrm{P}), 25 \mathrm{nmol}$ each) and analyzed by two dimensional thin layer cellulose electrophoresis, using $750 \mathrm{~V}$ for each dimension. The each radio activity from phospho-serine, phospho-threonine and phosphotyrosine spots was quantitated using BAS phosphoimager (Kodak). 


\section{Results}

\section{Expression and purification of CDK4/cyclin D1 and CDK2/cyclin A using baculoviral system}

CDK4 and CDK2 are known to form a specific complex with cyclin D1 and cyclin A respectively to become enzymatically active (Morgan, 1995). To obtain active CDK4/cyclin D1 heterocomplex protein, the sf9 cells were coinfected with the baculoviruses carrying full length CDK4 gene tagged with GST gene in its $\mathrm{N}$ terminal along with the viruses carrying a full length cDNA of cyclin D1. Fusion of C-terminus of glutathione $S$ transferase gene to CDK4 gene for the affinity purification of expressed protein resulted in the increased solubility of CDK4 protein after overexpression in sf9 cells. Without fusion to GST, CDK4 protein tends to form an inclusion body after being overexpressed (data not shown). The two expressed proteins were expected to form a complex within cells (Kato et al., 1994). The purified protein using glutathione bead affinity column chromatography, contained both CDK4 protein and cyclin D1 (Figure 1A). In the Mono $Q$ column chromatography. GST-CDK4/ cyclin D1 complex protein was eluted as a single symmetrical peak at $0.4 \mathrm{~N} \mathrm{NaCl}$ (Figure 1B). This result indicates a tight association between CDK4 and cyclin D1. CDK2/cyclin A protein was similarly obtained after cotransfection of baculovirus carrying CDK2 and cyclin A. Hexahistidine tagging in N-terminal CDK2 gene enabled the purification of CDK2/cyclin A complex protein over $90 \%$ homogeneity by a single $\mathrm{Ni}^{2+}$ affinity purification (data not shown). This purified protein was used for subsequent biochemical characterizations.

\section{Development of CDK2/cyclin A and CDK4/cyclin D1 enzyme assay protocol}

In order to measure CDK2/cyclin A and CDK4/cyclin D1 enzyme activity quantitatively, we have developed a p81 filter binding assay method using hexa histidine tagged RB C-terminal protein (RBC) as a substrate and it is schematically described in Figure 2. RB C-terminal protein (amino acid; 780 to 928 ) has a positive charge at neutral $\mathrm{pH}$ (PI value; 10.4). Spotting the reaction mixture onto $p 81$ cellulose filter and washing subsequently with $20 \mathrm{mM}$ Phosphate buffer ( $\mathrm{pH}$ 6.0) containing $0.1 \mathrm{M} \mathrm{NaCl}$ retains the $\mathrm{RBC}$ protein on the paper whereas unreacted negatively charged free ATP is almost washed away. The degree of phosphorylation of RBC by CDK2 or CDK4 activity does not interfere with the protein binding onto p81 filter paper.

\section{$\mathrm{Km}$ value of CDK4/cyclin D1 for ATP is very high compared to that of CDK2/cyclin $A$}

$\mathrm{Km}$ value for ATP and turn over rate of CDK4/cyclin $D 1$ and $C D K 2 /$ cyclinA were determined respectively. CDK4/cyclin D1 and CDK2/cyclin A use dual substrates such as ATP and RB protein. In this measurement, we used $20 \mu \mathrm{M}$ of purified human RB C-terminal protein (a.a. 780 to 928 ) as a substrate. However with this RB concentration, enzyme activity still did not reach to maximum (data not shown). However, because increase over this RB concentration caused experimental inconveniences, we performed all enzyme kinetic experiments at $20 \mu \mathrm{M}$ of $\mathrm{RBC}$ concentration. From the reciprocal plot (Figure $3 \mathrm{~A}$ ), $\mathrm{Km}$ of CDK2/ cyclin A for ATP was measured as $23 \mu \mathrm{M}$ and this value is similar to $\mathrm{Km}$ for ATP of most other protein kinases involved in signal transductions (Su et al.,
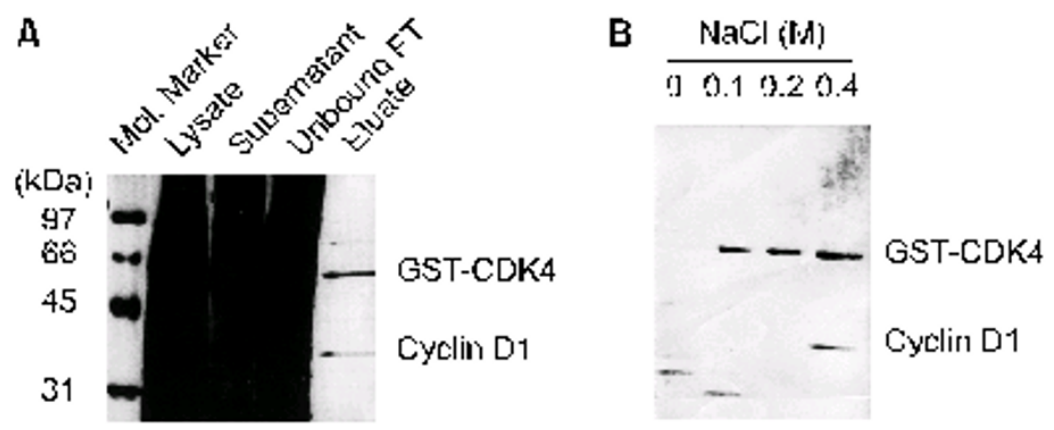

Figure 1. Purification of CDK4/cyclin D1. (A) One L culture of sf 9 cells coinfected with GST-CDK4 and cyclin D1 baculovirus was lysed by sonication and centrifuged. The soluble supernatant was subjected to glutathione-agarose affinity column chromatography. After washing unbound flow-through proteins, the bound protein was eluted with $5 \mathrm{ml}$ of buffer containing $20 \mathrm{mM}$ reduced glutathione. Each protein sample in the course of chromatographic step was added with equal volume of $2 \times$ Laemli buffer and electrophoresed in $10 \%$ SDS-polyacrylamide gel. The gel was stained with Coomassie brillant blue. Lysate: total lysate, Supernatant: supernatant after centrifugation. Unbound FT: unbound flow through. Eluate; eluate with $20 \mathrm{mM}$ reduced glutathione. (B) The eluate from glutathione column was applied to Q-sepharose ion exchange column chromatography. The bound protein was gradually eluted by stepwise increase of $\mathrm{NaCl}$ concentration. Each fraction was added with equal volume of $2 \times L$ Laemli buffer and electrophoresed in 10\% SDS-polyacrylamide gel. The gel was stained with Coomassie brillant blue. 
1996). However $\mathrm{Km}$ of CDK4/cyclin D1 for ATP showed a value of $418 \mu \mathrm{M}$ (Figure $3 \mathrm{~B}$ ). Compared to other cellular regulatory kinases, this is an abnormally high $\mathrm{Km}$ value for ATP. Next, we measured the turnover rate of the two CDK kinases. In the measurement, we used $1 \mathrm{mM}$ of ATP and $20 \mu \mathrm{M}$ of RBC protein concentration. The reason why we used ATP concentration of $1 \mathrm{mM}$ is due to the high $\mathrm{Km}$ value for ATP

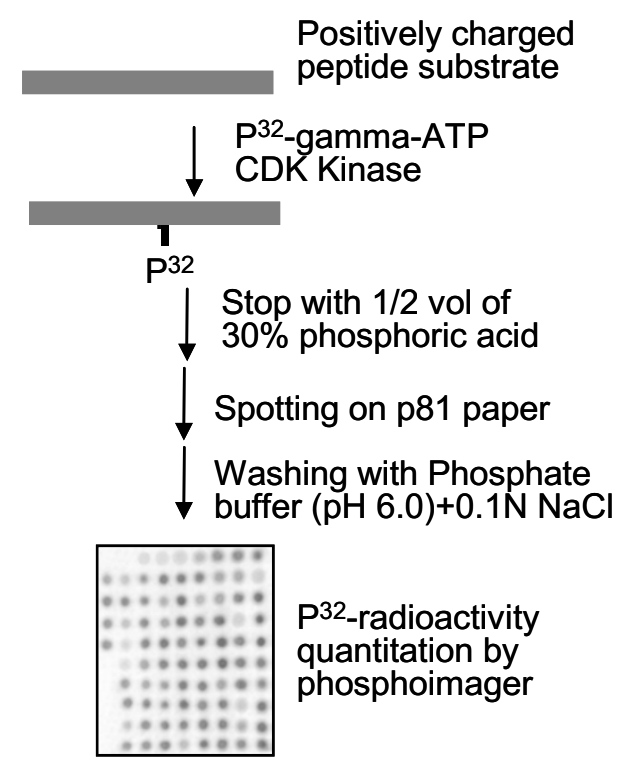

Figure 2. Schematic representation of $p 81$ filter binding assay for CDK2/cyclin A and CDK4/cyclin D1. Detailed explanation is described within the text.

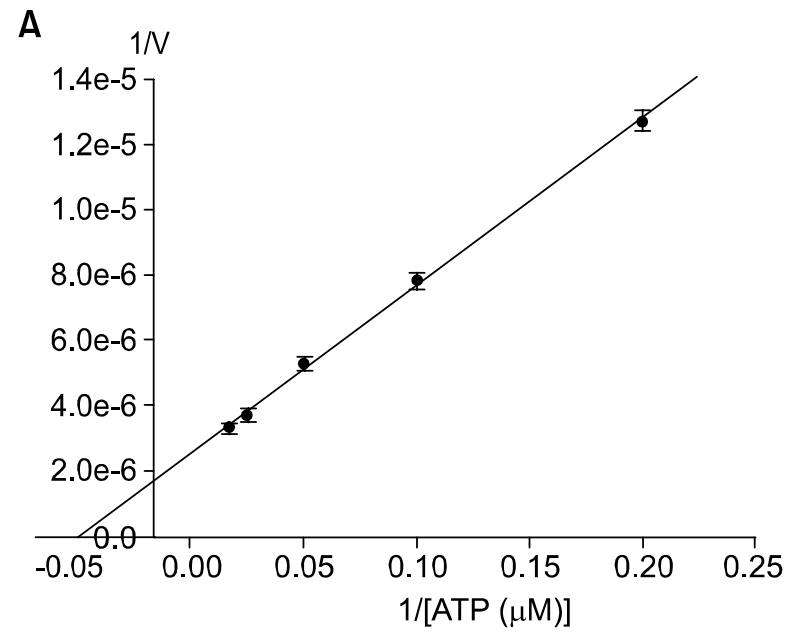

of CDK4/cyclin D1. In these substrate concentrations, CDK2/cyclin A gives transfer of 3.4 pmole phosphate per min, per pmole enzyme. This turnover rate value of CDK2/cyclin A shown here was similar to the previously reported value of 3.8 pmole per min per pmole enzyme for in vitro activated CDK2/cyclin A (Jeffrey et al., 1995). This means that the purified CDK2/cyclin A enzyme from sf9 cells is in the active state. On the other hands the turn over rate of CDK4/cyclin D1 was measured as 3.9 pmole per min per pmole enzyme. This value is slightly higher than that of CDK2/cyclin $A$, indicating that CDK4/cyclin D1 we purified is as much an active form as CDK2/cyclin A. However, their $\mathrm{Km}$ values for ATP are different by 18 fold. Kinetic efficiency (turnover number over $\mathrm{Km}$ ) estimation indicates over one order magnitude less efficiency for CDK4/cyclin D1 than CDK2/cycline A $(9.3$ $\mathrm{pM}^{-1} \mathrm{~min}^{-1}$ for CDK4/cycline D1 and $170 \mathrm{pM}^{-1} \mathrm{~min}^{-1}$ for CDK2/cycline A). Intracellular ATP concentration that varies from $10 \mu \mathrm{M}$ to $1 \mathrm{mM}$ has been shown to be a regulatory factor for p27 protein to regulate cell cycle (Sheaff et al., 1997). Our data suggest that the intracellular ATP concentration could be an important regulatory factor for in vivo CDK4/cyclin D1 activity because its $\mathrm{Km}$ value is so high that a high local ATP concentration such as $1 \mathrm{mM}$ is required for most CDK4/cyclin D1 within cells to work.

\section{Inhibition of cellular CDK4 activity changes the intracellular ATP concentration}

Given the interesting possibility that cellular CDK4/ cyclin D1 activity depends on cellular ATP concen-

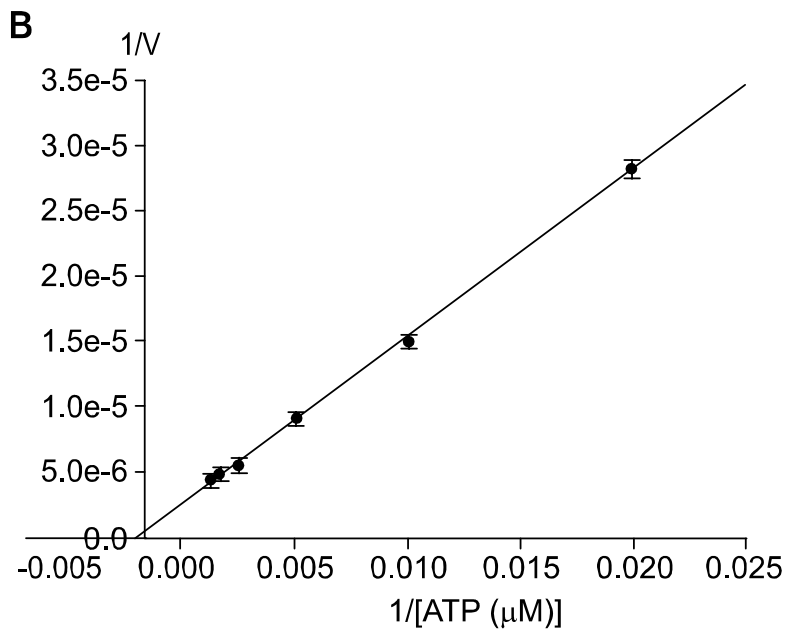

Figure 3. Reciprocal plotting of $1 / \mathrm{V}$ versus $1 /[\mathrm{ATP}]$ for CDK2/cyclin A and CDK4/cyclin D1. (A) With the variation of ATP concentration, CDK2/cyclin A enzymatic activity was measured with triplicate by the standard assay condition and the reciprocal plot of $1 /$ relative activity (1/V) vs $1 /[\mathrm{ATP}]$ was plotted. At least three measurements of the kinase activity were done. A straight line was obtained by linear regression. The Km for ATP was calculated from $x$-intercept. (B) With the variation of ATP concentrations, CDK4/cyclin D1 enzymatic activity was measured with triplicate by the standard assay condition and the reciprocal plot of $1 /$ relative activity (1/V) vs $1 /[$ ATP] was plotted and Km for ATP was obtained from $x$-intercept. 
tration, we next examined a possibility that inhibiting CDK4/cyclin D1 in cells could change cellular ATP concentration. When we treated HepG2 cells with 2 $\mu \mathrm{M}$ of Flavopiridol, a specific CDK4 inhibitor (Bible et al., 1996), cellular ATP concentration increases up to about 3 fold during $8 \mathrm{~h}$ treatment (Figure 4). This increase occurs ahead of cell cycle arrest that is observed normally from $12 \mathrm{~h}$ after Flavopiridol treat-

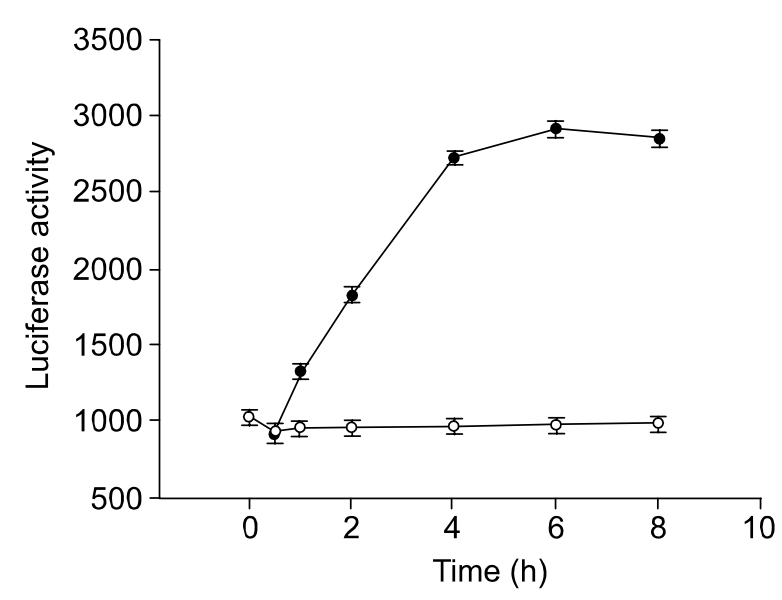

Figure 4. Measurement of cellular amount of ATP. Hep G2 cells were treated with $2 \mu \mathrm{M}$ of Flavopiridol (filled circle) or $20 \mu \mathrm{M}$ of roscovitine (open circle) for indicated times. Cells were harvested in $500 \mu \mathrm{l}$ of lysate buffer and $10 \mu \mathrm{l}$ was used to measure the luciferase activity using the ATP measuring kit from Sigma as described by the manufacturer. Three measurements were done and the luciferase activity was plotted at each treated time with standard deviation. The luciferase activity of each lysate represents the relative ATP concentration in the cell lysate. ment (Bible et al., 1996). At this time, it is not clear why inhibition of CDK4 makes cellular amount of ATP increased. On the other hand, inhibition of cellular CDK2 activity by treating HepG2 cells with its specific inhibitor, Roscovitine $\left(\mathrm{IC}_{50}: 500 \mathrm{nM}\right)$ for $8 \mathrm{~h}$ did not give any considerable change of cellular ATP concentration (Figure 3). Along with the fact that $\mathrm{Km}$ of CDK4/Cyclin D1 for ATP is $418 \mu \mathrm{M}$, this data emphasize the possibility that regulation of cellular CDK4/ cyclin D1 activity is tightly associated with the cellular concentration of ATP.

\section{Preferential phosphorylation sites in RB C-terminal are different between CDK4/cyclin D1 and CDK2/cyclin $A$}

CDK4/cyclin D1 and CDK2/cyclin A belong to proline directed kinases, that phosphorylate serine or threonine ahead of proline residue and are shown to share a preferential consensus peptide substrate sequence, (S/T) PX (R/K) (Endicott et al., 1999). The phosphorylation of RB C-terminal domain is known to free transcription factor $E 2 F$ from $R B$ binding, thus activates E2F dependent gene expressions (Draus et al., 2001; Stevens et al., 2003).

Even though RB C-terminal phosphorylation by CDKs has been well known so far, detailed differences in this phosphorylation by each CDK are barely known. In order to exploit possible differences in the phosphorylation of RB C-terminal sites by CDK4/cyclin D1 and CDK2/cyclin A, we performed phospho-amino acid analysis on RB C-terminal peptide (a.a. 780 to 928) after enzymatic reaction with these CDKs. There
A

SPIPHIPRSPYKFPSSPLRIPGGNIYI SPLKSPYKISEGLPTPTKMTPRSRI LVSIGESFGTSEKFQKINQMVCNSD RVLKRSAEGSNPPKPLKKLRFDIEG SDEADGSKHLPGESKFQQKLAEMT STRTRMQKQKMNDSMDTSNKEEK

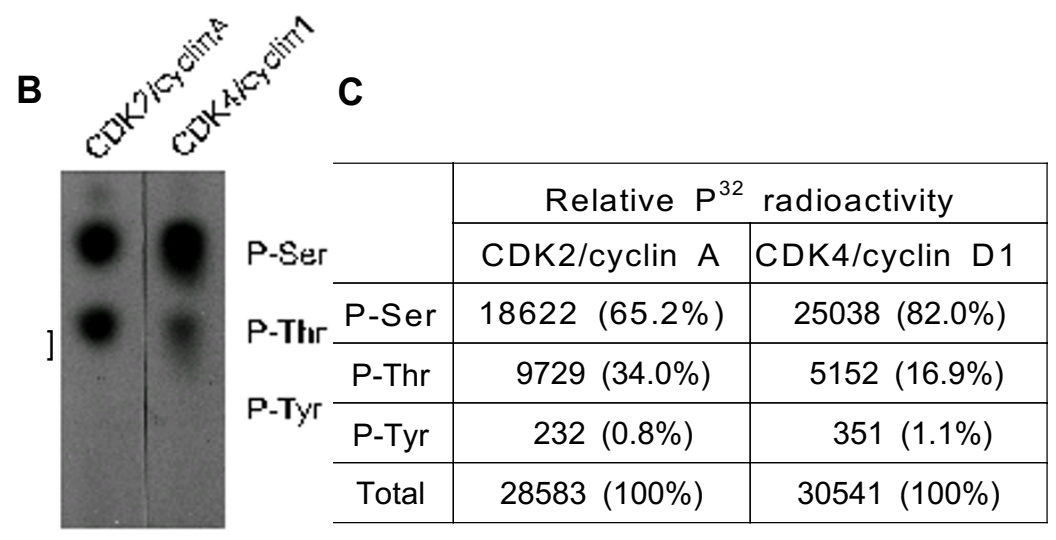

Figure 5. Phospho-aminoacid analysis of human RB C-terminal domain after phosphorylation reaction by CDK2/cyclin A or CDK4/cyclin D1. (A) Amino acid sequence of the RB C-terminal (a.a. 780 to 928) are shown and the possible phosphorylation sites of serine and threonine residues are marked with rectangular boxes. (B) After the phosphorylaton reaction using $\mathrm{P}^{32}$-ATP, the RB C-terminal protein was separated in $15 \%$ SDS-PAGE gel and transferred to PVDF membrane. The radioactive RB band was excised and hydrolyzed. The mixture of hydrolyzed amino acids were separated on TLC plate along with cold phosphoserine, phosphothreonine and phosphotyrosine as references. The radioactivity on each assigned phosphoamino acid was autoradiographed. (C) The radioactivity on each spot was quantitated using BAS $\mathrm{P}^{32}$ phospho-imager (Kodak) and summarized along with \% value in parenthesis compared to the sum of radioactivity from all three spots. 
are seven possible sites that can be phosphorylated by CDKs within this peptide (Figure 5A). Among these residues, five are serines and two are threonines as depicted by letters within rectangle box in Figure $5 \mathrm{~A}$. In the phosphorylation by CDK2, the ratio of $\mathrm{p}^{32}$ radioactivity distribution in serine spot: threonine spot: tyrosine spot is $65.1: 34.0: 0.9 \%$ respectively. Whereas, in case of CDK4, its distribution in serine spot: threonine spot: tyrosine spot was $81.9: 16.9: 1.1 \%$ respectively (Figure $5 B$ and $C$ ). These data indicate that CDK2/cyclin A tends to phosphorylate two threonine residues with about 2 fold higher preference than CDK4/cyclin D1. In addition, CDK4/cyclin D1 prefers serine residues for its phosphorylation site more than CDK2/cyclin A does. This differential preference for phosphorylation site between two CDKs will result in differently phosphorylated RB C-terminal proteins. At this time it is not clear the functional significance of this differential phosphorylation between two CDKs. However, we interpret that differential phosphorylation of RB C-terminal by CDK2 and CDK4 would be necessary for cell cycle stage dependent association and dissociation of RB protein with its specific binding proteins. This is based on the fact that more than 10 proteins are known to bind RB protein (Weinberg, 1995) and most of these bindings are shown to be affected by serine/threonine phosphorylation in RB $\mathrm{C}$-terminal. The sum of $\mathrm{p}^{32}$ radioactivity in the spots of all three amino acids after the phospho-amino acid analysis reaction was almost identical between CDK2/cyclin A and CDK4/cyclin D1 (Figure 5C). This indicates two enzymes share a similar reaction rate when ATP is provided sufficiently, confirming the similar turn over rates between them as shown above.

p16 inhibition of CDK4/cyclin D1 activity is potent and may not be interfered by the complex formation between CDK4 and cyclin D1

p16 is known to bind tightly to CDK4 protein and inhibits CDK4/cyclin D1 enzymatic activity, probably by preventing CDK4 from forming an active structural confirmation exerted by binding of cyclin D1 (Pavletich, 1999; Russo et al., 1998). When we measured the potency of this inhibition using the standard assay, it gives about $3 \mathrm{nM}$ of $\mathrm{IC}_{50}$ value (Figure 6). Whereas Flavopiridol, a compound under the clinical trial (Bible, 1996; Knockaert et al., 2002) as CDK4 inhibitor showed $60 \mathrm{nM}$ of $\mathrm{IC}_{50}$ in a parallel measurement similar to the reported value of $70 \mathrm{nM}$. As reported previously, p16 did not inhibit CDK2/cyclin $A$ (data not shown). This confirmed that $p 16$ is a very potent and selective inhibitor against CDK4/cyclin D1. Next we performed this inhibition assay with a preincubation of $\mathrm{p} 16$ and CDK4/cyclin D1 for an hour before subject to inhibition assay on a purpose to give

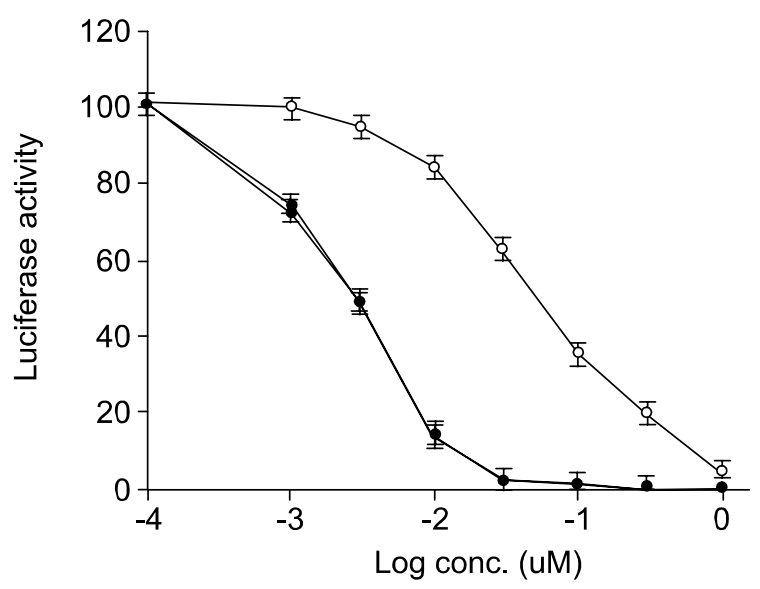

Figure 6. Inhibition of CDK4/cyclin D1 activity by its inhibitors. In the absence or presence of various amounts of purified p16 protein with or without preincubation, inhibition assay was performed 3-5 times under the standard assay condition. In a same way, inhibition by Flavopiridol was performed as well and compared to that by $p 16$. Percent of relative CDK4/cyclin D1 activity compared to the activity without inhibitor at various concentrations of inhibitors was plotted with standard deviations. $\mathrm{IC}_{50}$ value was assigned as the concentration of inhibitor that gives $50 \%$ inhibition of CDK4/cyclin D1 activity. filled circle; inhibition curve by $\mathrm{p} 16$ without preincubation, filled triangle; inhibition curve by 16 with preincubation, open circle; inhibition curve by Flavopiridol.

an enough time to interefere CDK4/cyclin D1 complex by $\mathrm{p} 16$. Interestingly this preincubation did not change the $I_{50}$ value (Figure 6 ). This suggests that the degree of complex formation between CDK4 and cyclin D1 does not affect the inhibition by $\mathrm{p} 16$ at all. In other words, p16 could inhibit CDK4 whether it is alone or complexed with cyclin D1 with a same efficiency.

\section{Discussion}

Cell proliferation is the fundamental basic process for life. In cell proliferation, development and differentiation, CDK4/cyclin D1 activity plays a pivotal regulatory role (Sherr, 1994; Ekholm et al., 2000). In this reason, cellular CDK4/cyclin D1 activity is tightly controlled by various positive and negative regulations. Its unbalanced regulation often results in diseases such as cancer (Sherr, 1996; Robles et al., 1998; Krimpenfort, et al., 2001). In this respect, the precise understanding of CDK4/cyclin D1 is important to elucidate the mechanisms of related diseases and develop their therapeutic intervention strategies. Most studies on the activities of CDK4/cyclin D1 have been done at cellular level. Therefore results presented here from the biochemical studies of purified CDK4/ cyclin D1 protein compared to CDK2/cyc A provide us with another crews for the better understanding of 
CDK4/cyclin D1.

One of interesting facts from this study is that the $\mathrm{Km}$ of CDK4/cyclin D1 for ATP is $418 \mu \mathrm{M}$. Most protein kinases involved in the signal transduction are known to have $\mathrm{km}$ for ATP in the range of $1-30 \mu \mathrm{M}$. Given that cellular ATP concentration varies from 10 $\mu \mathrm{M}$ to $1 \mathrm{mM}$, cellular CDK4/cyclin D1 activity should depend significantly on the variation of intracellular ATP concentration. In other words, control of intracellular ATP concentration could be one of key tools to regulate the cellular activity of CDK4/cyclin D1. Another interesting data shown here to suggest a possible tight relationship between CDK4/cyclin D1 activity and intracellular ATP concentration is that the inhibition of cellular CDK4 activity by its specific pharmacological inhibitor, Flavopiridol increases the cellular ATP content whereas the inhibition of CDK2 activity by its known inhibitor, Roscovitine does not give any significant effect on cellular amount of ATP. The reason for increase of ATP upon cellular CDK4 inhibition is not clear at this time. One of possible interpretations is that cells might resist to an abrupt cell cycle blocking by increasing cellular ATP content. The inhibition of CDK2/cyclin A by p27 is known to be dependent on cellular amount of ATP (Sheaff et al., 1997). According to the paper, high concentration of ATP causes the ATP binding pocket of CDK2 filled by ATP, which lead to CDK2/cyclin A activity free from the inhibition by p27. In supporting this observation, it has been shown from the X-ray crystallographic study that the binding region of p27 in CDK2 includes ATP binding pocket (Jeffrey et al., 1995). Taken together, these observations imply that cellular ATP concentration plays a role in the regulation of cell cycle process. In addition, ATP is known to have mitogenic activities in several cells (Chung et al., 1997). However we need more works to decipher molecular mechanisms for the increase of cellular ATP amount upon the inhibition of CDK4/cyclin D1 activity.

RB is phosphorylated in cycling cells and becomes unphosphorylated as cells are arrested in G0/G1 (Goodrich et al., 1991; Lin et al., 1991). The phosphorylation of RB is known to affect its binding to other proteins such as E2F and this is one of the main mechanisms to regulate cellular RB function (Stevens, 2003). in vitro, all of CDK1, CDK2 and CDK4 can phosphorylate RB and the phosphorylated sites exist mostly in its C-terminal region (Endicott, 1999). However, each CDK has a distinct role in its corresponding cell cycle phase. It is possible to speculate that each CDK might phosphorylate serine and threonine residues in $\mathrm{RB} C$-terminal with a different pattern from other CDKs and this might contribute to a distinct complex formation between RB and cellular proteins depending on a specific cell cycle phase. In data presented here, it is confirmed that CDK2 and CDK4 generate differently phosphorylated RB C-terminal proteins. We postulate that this different phosphorylation pattern might be necessary for the regulation of interactions between RB and cellular proteins differently in mid $\mathrm{G} 1$ and $S$ phase. However, in order to elucidate a concrete cellular meaning of this differential phosphorylation in respect of cell cycle regulatory function by RB, further studies should be necessary.

The reason why CDK4/cyclin D1 draws a lot of research interests is that its activated activity is directly linked to cancer (An et al., 1999; Krimpenfort et al., 2001; Sotillo et al., 2001). This fact has stimulated a lot of research efforts to develop its specific inhibitors as an anticancer agent (Senderowicz et al., 2000; Knockaert et al., 2002). Two CDK4/cyclin D1 inhibitors have been tested extensively for therapeutic possibility of cancer. One is p16, a natural specific protein inhibitor and the other is a small molecular weight chemical, flavopiridol (Bible et al., 1996; Liggett et al., 1998; Harrington et al., 2001). So far the exact degree of inhibition of CDK4/cyclin D1 by p16 has not been published yet. In this study, we obtained $3 \mathrm{nM}$ of $\mathrm{IC}_{50}$ value for $\mathrm{p} 16$ while flavopiridol gave $70 \mathrm{nM}$ of $\mathrm{IC}_{50}$ value. This indicates the inhibition by $\mathrm{p} 16$ is very potent, compared to the chemical inhibitor, flavopiridol. p16 protein is known to bind to monomeric CDK4 protein. The fact that preincubation of CDK4/cyclin D1 with p16 before starting enzyme inhibition reaction did not improve the measured $\mathrm{IC}_{50}$ value at all suggests that CDK4 binding to p16 is much more preferential over its association with cyclin D1. These inhibitory features could make p16 as a good molecule for targeting in vivo CDK4 activity in cancer cells. However its delivery technique into cancer cells within body could be a big huddle to develop it as a therapeutic purpose.

\section{References}

Aktas H, Cai H, Cooper GM. Ras links growth factor signaling to the cell cycle machinery via regulation of cyclin D1 and the Cdk inhibitor p27KIP1. Mol Cell Biol 1997;17:3850-7

An HX, Beckmann MW, Reifenberger G, Bender HG, Niederacher D. Gene amplification and overexpression of CDK4 in sporadic breast carcinomas is associated with high tumor cell proliferation. Am J Pathol 1999;154:113-8

Baldin V, Lukas J, Marcote MJ, Pagano M, Draetta G. Cyclin $D 1$ is a nuclear protein required for cell cycle progression in G1. Genes and Development 1993;7:812-21

Bible KC, Kaufmann SH. Flavopiridol: a cytotoxic flavone that induces cell death in noncycling A549 human lung carcinoma cells. Cancer Res 1996;56:4856-61

Brechot C. Oncogenic activation of cyclin A. Curr Opin Genet 
Dev 1993;3:11-8

Chung T, Crilly KS, Anderson WH, Mukherjee JJ, Kiss Z. ATP-dependent choline phosphate-induced mitogenesis in fibroblasts involves activation of pp70 S6 kinase and phosphatidylinositol 3'-kinase through an extracellular site. J Biol Chem 1997;272:3064-72

Draus JM, Elliott MJ, Atienza C Jr, Stilwell A, Wong SL, Dong $\mathrm{Y}$, Yang $\mathrm{H}$, McMasters KM. p53 gene transfer does not enhance E2F-1-mediated apoptosis in human colon cancer cells. Exp Mol Med 2001;33:209-19

Ekholm VS, Reed IS. Regulation of G1 cyclin-dependent kinases in the mammalian cell cycle. Curr Opin Cell Biol 2000;12:676-84

Endicott AJ, Noble EM, Tucker AJ. Cyclin-dependent kinases: inhibition and substrate recognition. Curr Opin Struct Biol 1999;9:738-44

Fry DW, Bedford DC, Harvey PH, Fritsch A, Keller PR, Wu Z, Dobrusin E, Leopold WR, Fattaey A, Garrett MD. A potent inhibitor of the cyclin D-dependent kinases CDK4 and CDK6. J Biol Chem 2001;276:16617-23

Goodrich DW, Wang NP, Qian YW, Lee EY, Lee WH. The retinoblastoma gene product regulates progression through the G1 phase of the cell cycle. Cell 1991;67:293-302

Guadagno TM, Ohtsubo M, Roberts JM, Assoian RK. A link between cyclin A expression and adhesion-dependent cell cycle progression. Science 1993;262:1572-5

Harrington KJ, Spitzweg C, Bateman AR, Morris JC, Vile RG. Gene therapy for prostate cancer: current status and future prospects. J Urol 2001;166:1220-33

Jeffrey PD, Russo AA, Polyak K, Gibbs E, Hurwitz J, Massagu J, Pavletich NP. Mechanism of CDK activation revealed by the structure of a cyclinA-CDK2 complex. Nature 1995;376:313-20

Kato JY, Matsuoka M, Strom DK, Sherr CJ. Regulation of cyclin D-dependent kinase 4 (cdk4) by cdk4-activating kinase. Mol Cell Biol 1994;14:2713-21

Kiyokawa H, Richon VM, Rifkind RA, Marks PA. Suppression of cyclin-dependent kinase 4 during induced differentiation of erythroleukemia cells. Mol Cell Biol 1994;14:7195-203

Knockaert M, Greengard P, Meijer L. Pharmacological inhibitors of cyclin-dependent kinases. Trends Pharmacol Sci 2002;23:417-25

Koff A, Giordano A, Desai D, Yamashita K, Harper JW, Elledge S, Nishimoto T, Morgan DO, Franza BR, Roberts $\mathrm{JM}$. Formation and activation of a cyclin E-cdk2 complex during the G1 phase of the human cell cycle. Science 1992; 257:1689-94

Krimpenfort P, Quon KC, Mooi WJ, Loonstra A, Berns A. Loss of p16Ink4a confers susceptibility to metastatic melanoma in mice. Nature 2001;413:83-6

Liggett WH Jr, Sidransky D. Role of the p16 tumor suppressor gene in cancer. J Clin Oncol 1998;16:1197-206

Lin BT, Gruenwald S, Morla AO, Lee WH, Wang JY. Retinoblastoma cancer suppressor gene product is a substrate of the cell cycle regulator cdc2 kinase. EMBO J 1991;
$10: 857-64$

Meyerson M, Enders GH, Wu CL, Su LK, Gorka C, Nelson C, Harlow E, Tsai LH. A family of human cdc2-related protein kinases. EMBO J 1992;11:2909-17

Morgan DO. Principles of CDK regulation. Nature 1995;374: 131-4

Nam DH, Song SY, Park K, Kim MH, Suh YL, Lee JI, Kim JS, Hong SC, Shin HJ, Park K, Eoh W, Kim JH. Clinical significance of molecular genetic changes in sporadic invasive pituitary adenomas. Exp Mol Med 2001;33:111-6

Nevins JR, Chellappan SP, Mudryj M, Hiebert S, Devoto S, Hunter T, Pines J. E2F transcription factor is a target for the RB protein and cyclin A protein. Cold Spring Harb Symp Quant Biol 1991;56:157-62

Pavletich PN. Mechanisms of Cyclin-dependent Kinase Regulation: Structures of Cdks, their Cyclin Activators, and Cip and INK4 Inhibitors. J Mol Biol 1999;287:821-8

Rao SS, Chu C, Kohtz DS. Ectopic expression of cyclin D1 prevents activation of gene transcription by myogenic basic helix-loop-helix regulators. Mol Cell Biol 1994;14:5259-67

Robles AI, Rodriguez-Puebla ML, Glick AB, Trempus C, Hansen L, Sicinski P, Tennant RW, Weinberg RA, Yuspa $\mathrm{SH}$, Conti CJ. Reduced skin tumor development in cyclin D1-deficient mice highlights the oncogenic ras pathway in vivo. Genes \& Development 1998;12:2469-74

Russo AA, Jeffrey PD, Patten AK, Massagu J, Pavletich NP. Crystal structure of the p27Kip1 cyclin-dependent-kinase inhibitor bound to the cyclin A-Cdk2 complex. Nature 1996; 382:325-31

Senderowicz AM, Sausville EA. Preclinical and clinical development of cyclin-dependent kinase modulators. J Nat Cancer Inst 2000;92:376-87

Serrano M, Hannon GJ, Beach D. A new regulatory motif in cell-cycle control causing specific inhibition of cyclin D/ CDK4. Nature 1993;366:704-7

Sheaff RJ, Groudine M, Gordon M, Roberts JM, Clurman BE. Cyclin E-CDK2 is a regulator of p27Kip1. Genes Dev 1997;11:1464-78

Sherr CJ. G1 phase progression: cycling on cue. Cell 1994; 79:551-5

Sherr CJ. Cancer cell cycles. Science 1996;274:1672-7

Sherr CJ, Roberts JM. CDK inhibitors:positive and negative regulators of G1-phase progression. Genes Dev 1999;13: 1501-12

Shin JY, Kim HS, Lee KS, Kim J, Park JB, Won MH, Chae SW, Choi YH, Choi KC, Park YE, Lee JY. Mutation and expression of the p27KIP1 and p57KIP2 genes in human gastric cancer. Exp Mol Med 2000;32:79-83

Sicinski P, Donaher JL, Parker SB, Li T, Fazeli A, Gardner $\mathrm{H}$, Haslam S Z, Bronson RT, Elledge SJ, Weinberg RA. Cyclin D1 provides a link between development and oncogenesis in the retina and breast. Cell 1995;82:621-30

Soni R, O'Reilly T, Furet P, Muller L, Stephan C, ZumsteinMecker S, Fretz H, Fabbro D, Chaudhuri B. Selective in vivo and in vitro effects of a small molecule inhibitor of cyclin- 
dependent kinase 4. J Nat Cancer Inst 2001;93:436-46

Sotillo R, Dubus P, Martn J, de la Cueva E, Ortega S, Malumbres $M$, Barbacid $M$. Wide spectrum of tumors in knock-in mice carrying a Cdk4 protein insensitive to INK4 inhibitors. EMBO J 2001;20:6637-47

Stevens C, La Thangue NB. E2F and cell cycle control: a double-edged sword. Arch Biochem Biophys 2003;412:15769

Su B, KM. Mitogen-activated protein kinase cascades and regulation of gene expression. Curr Opin Immunol 1996;8: 402-11

Suzuki-Takahashi I, Kitagawa $M$, Saijo $M$, Higashi $H$, gino $H$, Matsumoto $H$, Taya $Y$, Nishimura S, Okuyama A. The interactions of E2F with $\mathrm{pRB}$ and with $\mathrm{p} 107$ are regulated via the phosphorylaton of $\mathrm{pRB}$ and $\mathrm{p} 107$ by a cyclin-A dependent kinase. Oncogene 1995;10:1691-8
Tan AR, Swain SM. Review of flavopiridol, a cyclin-dependent kinase inhibitor, as breast cancer therapy. Semin Oncol 2002;29:77-85

Wang CY, Petryniak B, Thompson CB, Kaelin WG, Leiden $J M$. Regulation of the Ets-related transcription factor Elf-1 by binding to the retinoblastoma protein. Science 1993;260: 1330-5

Weinberg, RA. The retinoblastoma protein and cell cycle control. Cell 1995;81:323-30

Welch PJ, Wang JY. A C-terminal protein-binding domain in the retinoblastoma protein regulates nuclear c-Abl tyrosine kinase in the cell cycle. Cell 1993;75:779-90 